After discharge home, infants with chronic lung disease have a higher risk of rehospitalisation with respiratory illness than infants of the same gestational age who do not have chronic lung disease. For example, one in eight infants with chronic lung disease requires readmission to hospital for respiratory syncitial virus bronchiolitis. Immunoprophylaxis with anti-respiratory syncitial virus antibodies may reduce hospital readmission rates. It is expensive, however, and has not been shown to be effective in reducing mortality or major morbidity, such as the need for mechanical ventilation. Parents can be reassured that infants with chronic lung disease have few clinically important respiratory problems in later childhood.

\section{Conclusion}

Advances in perinatal care, particularly the use of mechanical ventilation, antenatal steroids, and exogenous surfactant replacement have improved outcomes for preterm infants. The incidence of chronic lung disease has not decreased, however, and further research is needed to define safe and effective ways to prevent and treat this condition. These efforts should continue in parallel with the development and evaluation of family centred treatments for chronic lung disease, such as home oxygen treatment programmes.

Jenny Fraser is specialist registrar and Moira Walls is a neonatal nurse at the neonatal intensive care unit, Ninewells Hospital and Medical School, Dundee.

The ABC of preterm birth is edited by William McGuire, senior lecturer in neonatal medicine, Tayside Institute of Child Health, Ninewells Hospital and Medical School, University of Dundee; and Peter W Fowlie, consultant paediatrician, Perth Royal Infirmary and Ninewells Hospital and Medical School, Dundee. The series will be published as a book in spring 2005.

Competing interests: For WMcG's competing interests see first article in the series.

BMJ 2004;329:962-5

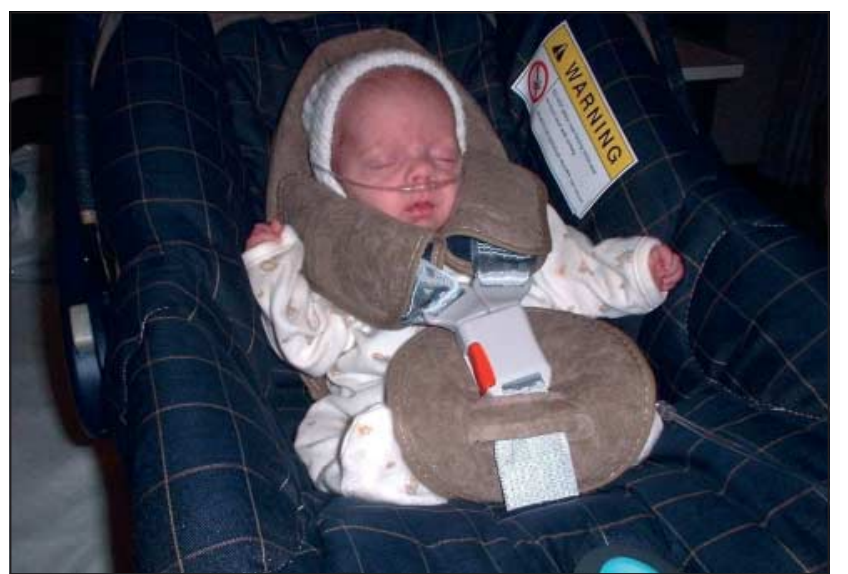

Home oxygen treatment allows earlier hospital discharge but parents are committed to the programme for at least several months while the supplemental oxygen is gradually reduced

\section{Further reading}

- Crowley P. Prophylactic corticosteroids for preterm birth. Cochrane Database Syst Rev 2003;(4):CD000065

- Soll RF, Morley CJ. Prophylactic versus selective use of surfactant in preventing morbidity and mortality in preterm infants. Cochrane Database Syst Rev 2003;(4):CD000510

- Greenough A, Milner AD, Dimitriou G. Synchronized mechanical ventilation for respiratory support in newborn infants. Cochrane Database Syst Rev 2003;(4):CD000456

- Henderson-Smart DJ, Bhuta T, Cools F, Offringa M. Elective high frequency oscillatory ventilation versus conventional ventilation for acute pulmonary dysfunction in preterm infants. Cochrane Database Syst Rev 2003;(4):CD000104

- Halliday HL, Ehrenkranz RA. Moderately early postnatal (7-14 days) corticosteroids for preventing chronic lung disease in preterm infants. Cochrane Database Syst Rev 2003;(1):CD001144

- Brion LP, Primhak RA, Ambrosio-Perez I. Diuretics acting on the distal renal tubule for preterm infants with (or developing) chronic lung disease. Cochrane Database Syst Rev 2003;(4):CD001817

- Wang EEL, Tang NK. Immunoglobulin for preventing respiratory syncytial virus infection. Cochrane Database Syst Rev 2003;(4):CD001725

\title{
Best laid plans
}

My grandmother, Nina Mary Hannaford, recently died after a long, productive, and inspirational life. A highly organised woman, she prepared for her death with detailed instructions for her funeral. She specified that she would prefer charitable donations rather than flowers, but that if flowers were to be sent these should be in bouquet form so they could easily be distributed to local care homes and hospices for others to enjoy.

Many beautiful floral tributes arrived for her, including pretty pastel displays from her great grandchildren and a bright red arrangement from the Labour party, of which she had been an active member. Only one tribute was a wreath that couldn't be used as Nina had requested. We were saddened since we didn't want such a beautiful display to go to waste, and the funeral directors suggested there was something we could do.

A few years previously a baby had been abandoned and sadly died, and was buried in a local cemetery. Since the family of the baby were never identified the grave was rarely visited. When possible, the funeral directors liked to place flowers on that grave, and they asked if we'd mind the wreath being placed there.

We agreed readily. Nina adored her own children, grandchildren, great grandchildren, and her many nieces and nephews-taking the time to write to and remember them all. She was also known as "Supergran" to countless other children she met at the local youth club that she had established and ran with her husband, Harry, until their retirement. It seemed right that the wreath that didn't quite fit Nina's specific instructions found itself in a much needed place. She would have been delighted.

Petra M Boynton lecturer, department of primary care and population sciences, University College London, London

(p.boynton@pcps.ucl.ac.uk)

We welcome articles up to 600 words on topics such as A memorable patient, A paper that changed my practice, My most unfortunate mistake, or any other piece conveying instruction, pathos, or humour. Please submit the article on http:// submit.bmj.com Permission is needed from the patient or a relative if an identifiable patient is referred to. We also welcome contributions for "Endpieces," consisting of quotations of up to 80 words (but most are considerably shorter) from any source, ancient or modern, which have appealed to the reader. 